\title{
Chapter 11 \\ The German Context: School Turnaround in Ten Schools in Difficult Circumstances: The Need for Adaptive and Contextualized Approaches to Development and Change
}

\author{
Guri Skedsmo and Stephan Huber
}

\begin{abstract}
In this chapter, we report on the research findings from a school development project which took place in a large city in Germany over a period of 5 years. In 2013, the central educational authorities formed a public-private partnership with a foundation to start a development project that was inspired by school turnaround models in the US and included various interventions and efforts to support change in ten schools that were identified as 'schools in difficult circumstances'. As such, the adapted school turnaround model serves as an example of introducing policies or models in school systems that have proven to be successful elsewhere. In this chapter, we present findings from our analysis of the changes taking place in the schools related to efforts and interventions to support the schools. Moreover, we discuss challenges regarding measurement of success according to the school turnaround logic and the need for more adaptive approaches for changing and developing schools in difficult circumstances - at least a long-term perspective on school development.
\end{abstract}

Keywords School Turnaround $\cdot$ School development and change $\cdot$ School leadership · Datafication · Quality indicators · Participation

\footnotetext{
G. Skedsmo $(\bowtie)$

Schwyz University of Teacher Education/University of Oslo, Oslo, Norway

e-mail: guri.skedsmo@phsz.ch
}

\author{
S. Huber \\ University of Teacher Education Zug, Zug, Switzerland \\ e-mail: stephan.huber@phzg.ch
}




\section{Introduction}

During the last two decades, increasing attention has been paid towards schools defined as 'failing,' 'low-achieving', 'underperforming,' or 'declining', a categorisation which, first of all, follows low student performance on standardised tests and consecutive years of failure in meeting targeted levels of achievement (Murphy \& Meyers, 2008; Meyer et al., 2021). The labeling of schools has emerged with increased datafication as a core element in education governance. Datafication is often used to characterise how different aspects of education are transformed into digital data, which makes it possible to connect these aspects and perform calculations on them (Williamson, 2017). As such, data represents a key to identify lowachieving schools, a basis to make decisions on strategies to improve, and to measure the progress and impact of interventions (Racherbäumer et al., 2013). This trend has given rise to policies and school development models that have proven to be successful in certain country contexts and promoted as 'evidence-based' (Bryk et al., 2015).

'School turnaround' is an example of a model proven to be effective in the United States (US) context. In the US, accountability policies have developed since the 1990s that aim to boost school performance in low-achieving schools. The idea of turning around such schools began to take form when it became clear that using rewards and consequences, in terms of sanctions on schools, proved to be a difficult strategy (Meyers, 2013). School turnaround is often described in terms of a specific strategy or model targeted at schools in difficult circumstances (Murphy, 2008). The following is an often-used definition:

Turnaround is a dramatic and comprehensive intervention in a low-performing school that: a) produces significant gains in achievement within two years; and b) readies the school for the longer process of transformation into a high-performing organization. (Kutash et al., 2010, p. 4)

Such models generally aim towards rapid improvement of student achievements combined with federal models for organisational change within school terms. More concretely, the local education agency (LEA) replaces the principals, evaluates the staff and rehires half of them, stresses the use of data-informed instruction and provides job-embedded professional development to build staff capacity (ibid.). Other federal models for organisational change in the US include various combinations of school closure, reopening or transformation of schools. Generally, such models are accompanied by transparency about results for important stakeholders, and accountability measures to create pressure that is intended to drive improvement and push key actors in schools to work harder (Webb, 2006; Mintrop, 2004).

In this chapter we report on research findings from a school development project, which took place in a large city in Germany over a period of 5 years. In 2013, the central educational authorities formed a public-private partnership with a foundation to start a development project involving ten schools. The project was inspired by school turnaround models in the US and included various interventions and efforts to support the schools. In the context of this project, turnaround was defined 
more broadly to include local and central authorities. Due to their complex problems as well as local governing contexts, schools were expected to improve with important stakeholders supporting them. The research question guiding our analysis is as follows: What characterises the 'turnaround process' in the ten participating schools and what kind of indicators are needed to identify and understand the changes?

The chapter is structured as follows: We start by presenting a short overview of previous research in the area of school development for schools in difficult circumstances. Second, we describe school turnaround policies in the US and similar attempts to improve schools in Germany, including this particular project. Furthermore, we also present some key characteristics of the German educational contexts and the structures of school systems. Third, we describe our methodological approach before presenting key findings of the project. Finally, we discuss these findings on changes in schools related to support efforts and interventions, the challenges regarding measurement of success according to the school turnaround logic and the need for more adaptive approaches for changing and developing schools in difficult circumstances.

\section{International Research on Key Characteristics and Initiatives to Improve Schools in Difficult Circumstances}

In addition to low student performance on standardised tests, key characteristics of low-achieving schools also often include school communities with a high number of families with low social economic status (SES), high degrees of migration etc., in combination with the school's dysfunctional organisation (e.g., Baumert et al., 2006). With respect to datafication and specific attempts to calculate the contribution of schools (value-added models), and even teachers, to student outcomes, these methods often control for SES and migration to produce 'fair' scores but lack other types of information to provide a comprehensive picture (Levy, 2019). It can be argued that these schools cannot be blamed for their surroundings, which, in many countries, are a consequence of the housing market and government policies, such as student enrollment and funding for educational materials.

Since the 1970s, international research into the effectiveness of schools has produced a fairly comprehensive level of knowledge that distinguishes successful schools. However, knowledge about the characteristics of dysfunctional school settings is still lacking. From an efficiency perspective, failing schools are sometimes described in terms of psychological dysfunction. Studies on ineffective schools show specific characteristics at the student level, the class level, and the school level, or they identify external causes (location) as well as internal causes (school). In summary, the following risk factors, which may lead schools into a spiral of decline, are identified in international scholarship (Altrichter et al., 2008; Altrichter 
\& Moosbrugger, 2011; Clarke, 2004; Harris \& Chapman, 2002; Hochbein, 2012; Murphy \& Meyers, 2008; Potter et al., 2002; Datnow \& Stringfield, 2000):

- Difficult conditions at home

- Student behavioural problems

- Strong student turnover

- Low student achievement levels

- Low teacher qualification levels

- Low degree of collegial cooperation among teachers

- High faculty turnover

- Lack of school management and leadership

More extensive experiences and findings on school development strategies for schools in difficult circumstance have been found in the US and England over the last few decades (Huber \& Mujis, 2012; Murphy \& Meyers, 2008; Muijs et al., 2004; Murphy, 2008; Ainscow et al., 2004). In general, differentiated measures tailored to each individual school are needed and not a panacea strategy. Moreover, schools need time to go through the following stages of development: a mission statement or audit; a school programme as well as the initiation, implementation and institutionalisation of suitable improvements; and an evaluation of the implementation and beginning of a new quality cycle (Huber et al., 2014; Meyers \& Hitt, 2017). However, there are some strategies that, according to the literature, are generally considered helpful for many schools (Huber, 2013):

- Rapid intervention with directly perceptible success

- Strengthening of the school administration

- Ensuring transparent objectives

- Initiating intensive continuous professional development

- Revising the curriculum

- Structuring teaching and learning processes

- Focusing on developing the school programme

- Defining clearer goals

- Strengthening cooperation and external support

- Inspection and accountability

- 'Reconstitution'- school closure and reopening after redesign

One limitation related to the aforementioned overview of international research is that most of these studies have been conducted in the US and England, two countries that have longer traditions of performance management systems with tools for measuring students' performance as well as policies and practices in place for holding key actors accountable for achieved results (Gunter et al., 2016). Therefore, further research is necessary in other countries to explore strategies for developing and supporting schools in difficult circumstances that meet challenges in specific contexts. 


\section{The German Education Context}

Over the last decade, strategies on how to improve schools in difficult circumstances have appeared on agendas in German-speaking countries with increasing frequency, along with the introduction of standardised testing and other indicators of school performance as part of evidence-based school governance. Some German federal states, such as the city-states of Hamburg, Bremen, and Berlin, have already addressed this issue by initiating projects where schools have been identified by quality indicators or early warning systems and followed up with interventions and support to 'turn around a circle of decline.' These projects have clearly been inspired by policies and strategies from the US, but attempts have been made to select and adapt ideas to fit German educational contexts.

As in the US, Germany has a federal structure where the responsibility for education lies basically with the 16 states and the federal government plays only a minor role. Kindergarten is optional and provided for all children between 1 and 6 years old. From the age of six, school attendance is compulsory. Primary education generally lasts 4 years (ages 6-9). After that, secondary education includes five school types, and students are normally streamed according to their achievements at the age of 10. Gymnasium prepares students for higher education and finishes with a final examination, Abitur, when students are 18 years old. Realschule prepares students to attend a professional or general education Gymnasium, vocational training or apprenticeship, after grade 10. Hauptschule prepares students for vocational education after grade 9. In some states, Realschule and Hauptschule have been merged and replaced by integrated secondary schools. Gesamtschule represents another integrated school type by combining Gymnasium, Realschule and Hauptschule. Even though inclusion policies have been promoted over the last decade, there are still various types of schools for special needs education and students with disabilities.

A federal structure and education, which is mainly a task for the states, are common characteristics of the American and German systems. Other system features vary, and one main reason may lie in the different curriculum traditions. In contrast to the American curriculum, the state's curriculum in Germany has not been seen as something that could or should explicitly direct teachers' work (Westbury et al., 2000). The curriculum (Lehrplan) lays out prescribed content and aims, and as such, it provides a framework for autonomous professional teachers to develop their own approach to teaching. In this work, the teachers are guided by a normative concept, Bildung, which refers to overall ideas of educating and bringing up children to engage productively and critically in democratic societies. To support them in this work, teachers apply Didaktik, which can be viewed as a system for thinking about and reflecting on problems of the curriculum related to teaching; therefore, it represents a larger rationale that teachers incorporate into their classroom work (Reid, 1998).

Recently, schools have been encouraged to develop local educational programmes congruent with the state curriculum (Huber et al., 2017). They do so by 
school-based curriculum renewal (often in intuitive ways). The state-run organisation, Landesinstitute, which exists in each of the 16 states, is expected to support the schools in their local curriculum development by means of consulting, providing materials, creating joint projects, qualifying teachers for new tasks and establishing school networks.

Along with the development of evidence-based approaches to school governing, Germany introduced standardised testing in seven states in 2004, and in the 2009-2010 school year, the VERA (VERgleichsArbeiten in der Schule) tests were expanded to all German states. Many scholars have noted the shock that was felt as the first results of the Programme for International Student Assessment (PISA) were published in 2001, one of the main drivers for introducing the tests to monitor student achievements over time (Hopmann, 2008). In addition, school inspections were established in several states, combined with school-based evaluations and work on school programmes to develop school quality (Böttcher \& Kotthoff, 2007; Altrichter \& Merki, 2010). Along with systems for monitoring student performance, new systems of control and accountability developed as well as national education standards (Bildungsstandards) and monitoring agencies (Quliatätsagenturen), which are run by each of the majority of the 16 states.

Projects in the city-states of Berlin, Hamburg and Bremen have resulted in approximately 15 years of experience in identifying and working with particularly low-performing schools (Huber, 2018). In Bremen, the action programme 'Schule macht sich stark' (SMS; literally 'School is getting strong') was implemented from 2004 to 2009 and marked the first nationwide school development project for schools in difficult circumstances, which was intended to strengthen and support the entire school development process. This project ran in parallel with a quality development campaign, which included the obligation to create annual work plans and school programmes and included external evaluations of all general education schools. The objectives of the project were to ensure mastering basic competencies (mathematics and German) and to increase student independence and responsibility for their own learning. The programme's activities included strengthening school leadership through coaching and counselling, staff development and teacher training, and diagnosing learning progress. The external coaching of the school administration and a network of the involved school management teams, which extend beyond the actual duration of the project, are considered to be particularly successful. In 2006, a process consulting method called 'proSchul' was established in Berlin, with the goal of providing schools in need of development with a seamless consultation process immediately after school inspections (Huber, 2018). The voluntary process consultation takes place in a triangular relationship between the school, proSchul, and the school inspectorate. In principle, this systematic approach to school development, characterised by goal orientation, transparency, strengthening collegial cooperation and communication by involving as many participants as possible, evaluation as a tool of process monitoring and systemic consideration of the organisation, teaching, and staffing, can be considered effective.

In Hamburg, the State Institute for Teacher Education and School Development carried out the project 'Unterstützung von Schulen in schwieriger Lage' (Supporting 
Schools in Difficult Circumstances) in 2007-2010. Focus was on support services in the developmental areas of teaching and teaching skills, teaching-related cooperation of the faculty and management and control of the development process (Huber, 2018). KESS-7 data and initial learning surveys in grade levels 5 and 7 of the participating schools were evaluated, and qualitative surveys with school administrators and faculty members were conducted. The project's coherence can be highlighted as successful because of the support provided for teaching, cooperation, management and control, each of which had a high level of adaptability for the individual school situation.

\section{Adapting a School Turnaround Approach in the German Context}

This chapter reports findings from a school turnaround approach, which was a collaboration between school authorities in a larger city in Germany and a private foundation (the Foundation). The project was inspired by school turnaround strategies applied in the US context. Due to regulations in the German education system, several of the organisational changes applied to turn around low-performing schools in the US are not possible in the German context. Thus, the organisational changes Meyers (2013) describes as central school turnaround strategies, in terms of replacing the principal and staff, would be illegal because the rights of employees are regulated by law in the German system. Key school turnaround strategies included several interventions, paid for by the Foundation, which mainly aimed to strengthen the capacity of schools to manage a turnaround process.

Four improvement areas were targeted by the project partners: (1) school leadership, (2) cooperation, (3) school culture and environment ('Schule als Lebensraum' which means 'school as living space'), (4) quality of teaching and learning processes and student outcomes.

The most important intervention was to provide each of the participating schools with a school development coach. The responsibility of the coach was to support the principal and the school towards change. Further interventions included:

- School leadership training

- Professional development for teachers

- Establishing networks between the project schools

- Internships or visits to other schools (e.g., visits to prize-winning schools which have developed concepts for teaching across age groups or have experience with adapted teaching)

- Development funds for each school in the sum of $€ 3000$

- School-based initiatives

Agreements with the schools, which included project specific aims, were signed by the principal and local authorities to commit the latter to prioritising support for 
the project schools, especially during the project period. These agreements were renewed for the second phase of the project.

The 10 project schools were selected by the central and local school authorities informed by the early warning system, an online system that put together different indicators of school quality, such as the number of students applying for school enrollment, teaching capacity, percentage of students with low SES, percentage of students with migrant backgrounds, VERA-results, and students' completion rate. This early warning system was also used by the school inspectorates. The project schools included three primary schools and seven lower secondary schools, which were located in five different areas of the city and, accordingly, five different local authorities.

In the initial project phase, an important task for the schools was to define project aims as part of a collective decision-making process, and they were asked to define areas where they could achieve 'quick wins,' similar to the rapid improvement strategy in the US context.

\section{Theoretical and Methodological Approaches}

For the overall research project, a theoretical model based on Cronbach et al. (1972) (cited in Ditton, 2002, p. 776) was adapted and applied. The model takes into account that for schools to successfully turn themselves around, concentrated efforts and actions had to be made in parallel on various levels: Input factors would need to improve, such as personnel and material resources, characteristics of the student population, finances, and the various conditions under which the schools operate. A major problem in all schools was that they did not have sufficient teaching personnel, and when teachers became ill, the situation worsened, and many lessons had to be cancelled. Material resources, for example, the school building and, in particular, the sanitation equipment for students in some schools, were in bad shape. Over half of the student population in each of the schools were exempted from paying for books and materials due to the SES of their families. Regarding improving these input factors, the schools needed extra support from both the LEA and Central Educational Authorities (CEA), and also needed to enhance their network in the local community.

The throughput factors included work on organisational structures, establishing a leadership team and middle-management and improving communication, coordination and cooperation throughout the school organisation.

Considering the aims of the project and previous research on developing schools in difficult circumstances, two types of output were defined: first, output on the school level, such as the perceptions of key actors (school leaders, teachers, support teams, students and parents) of the overall quality of the school, including teaching and learning environments. For school staff, a particular focus was directed towards perceptions of their work conditions. The second type of output includes student outcomes (e.g., the results of VERA tests and student completion rates) (Fig. 11.1). 


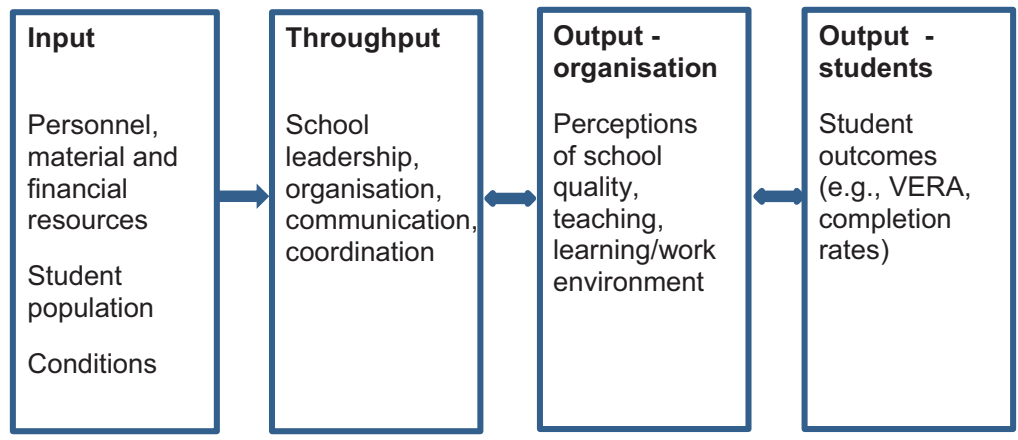

Fig. 11.1 Theoretical approach: input, throughput and output factors (Huber et al., 2017)

The logic of the model implies that coordinated support and interventions targeted towards input and throughput factors would lead to school improvements on organisational and student levels, but also that the interplay between throughput and output factors are important. This model differs from prevailing school turnaround models due to its focus on throughput factors rather than factors such as exchanging school staff and student output.

The research project draws on a mixed methods and longitudinal design, which included three rounds of semi-structured interviews with actors in the participating schools $(3 \times 80$ interviews from the first, third and fifth year with school leaders, teachers, support staff, students and parents in the project schools), and interviews from the first and final years with project stakeholders and system actors $(2 \times 27$ interviews with the project leaders, the reference group, coaches, local authorities, representatives from the state authority, and the Foundation).

Three surveys were conducted among school staff: teachers and school leaders in the project schools and in the 15 comparison schools in the first, third, and final years of the project (response rates: 44-48\%).

For the quantitative analysis, we examined changes in results on different scales over time, as measured by Cohen's d. We looked at the partial correlation network with the Least Absolute Shrinkage and Selection Operator (LASSO) between different scales to identify stable correlation patterns. Moreover, we analysed differences in the correlation patterns between different scales over time and conducted a path analysis.

For the qualitative analysis in this chapter, we have focused on interview data from principals, teachers, school development coaches and representatives from the LEA. As such, the analysis focused on creating meanings and structures of organisational realities and change seen from multiple perspectives in the school system (cf. Connelly et al., 1999). The data selected for the analysis serve as examples to deepen and understand the key findings from the quantitative analysis. 


\section{Presentation of Findings}

In the following, we concentrate on describing some of the main identified changes in the schools that demonstrate the importance of using various indicators on organisational and student levels and that recognise the importance of various factors in the development of schools in difficult circumstances. After this, we discuss the indicators used to evaluate the success of the overall project, as well as improvement logic in prevailing school turnaround approaches in the US.

An important finding in this project is the strengthened position of the principals and mid-level leaders as perceived over time by the school staff. The figure below is based on the quantitative analysis of survey data among teachers and leaders in the 10 schools. The model shows that school leadership has positively influenced how staff perceive their work conditions, which has enhanced the capacity for innovation and cooperation among teachers and support personnel, which in turn has positively impacted how the staff evaluate their overall work environment (Fig. 11.2).

Based on the qualitative study, we will describe in the following sections factors contributing to this chain of positive development in more detail, such as school leadership, time, support and important indicators of organisational change in the participating schools.

\section{Leadership as a Key to Improvement}

Findings from both the qualitative and quantitative studies showed that a wellfunctioning school leadership was key to improvement. The quantitative study showed that the strategic school leadership was generally strengthened during the project time - the contributions of mid-level leaders were especially considered by staff as increasingly important for motivating and initiating change. These results align with the focus of interventions in the project, and project schools developed significantly more in these areas than the comparison schools. In addition, staff reported improved information flow and transparency as related to distribution of tasks and responsibilities.

In 9 out of 10 schools, a change of principal took place either before the project started or during the lifetime of the project. The reasons for the changes before the

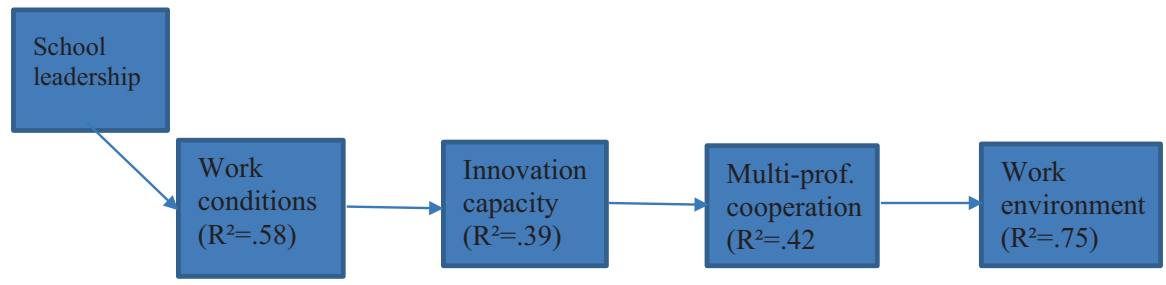

Fig. 11.2 Positive changes identified in the project schools (Huber et al., 2017) 
start of the project were that principals were retiring. In three schools, a second leadership change took place during the project due to highly problematic situations in the schools. Before the change, the principals received coaching from the school development coach and additional support from LEA, but eventually the principals' contracts were terminated, and new principals were hired.

For two schools in particular, the principal was described as the 'engine' of the development process. On the one hand, this is described positively. One the other hand, the teachers find it difficult to keep up with the speed of the principal. In three schools, there were challenges with the school leadership team during the first 2-3 years of the project, and it proved difficult for the principal to start the change process when he or she was legitimised formally (due to their preliminary position as principal or having had a position as a deputy principal) to lead the change. In one of the schools, the teachers described that 'innovations were passively tolerated.' However, as the school attained a new principal, they experienced that 'she brought with her necessary drive and structures to really start the process - and we are now in the middle of a change process' (Interview 3, 2017, Teacher, School A).

In several schools, the teachers describe the importance of principals in concentrating on building relationships with them. This seems to be an important factor for developing a basis for change. The process is often described by teachers in terms of managing to align various leadership tasks and concerns; for instance, to give clear direction and secure staff commitment, or to make unpopular decisions, and at the same time, take time to listen to their concerns and provide support. In one school, this was described by teachers as the principal promoting a welcoming culture just by keeping her door open: 'By this, she showed clearly that "I am here". If you went inside, she always listened - it was not only an open door' (Interview 1, 2013, Teacher, School C).

The teachers in this school describe the strength of the principal in her collective focus when initiating and driving development projects. It was important for her that the staff agreed to move collectively in a certain direction, and joint discussions were an important strategy to manage this:

I think she worked intensively to initiate discussions around key ideas. Mrs. X was one of the first leaders - she has not worked in our school that long - who, from the beginning, understood the importance of a joint discussion, and then decided in what direction we move (Interview 2, 2015, Teacher, School C).

The second interview round especially revealed that all the schools, independent of their project aims and with the support of the development coaches, had spent the first 2 years of the project improving the school's organisation. In particular, the principals focused on setting up the leadership team, consisting of the principals and mid-level leaders, and using these new structures to improve communication with staff. According to interviews with the development coaches as well as their written logs, they supported the schools mainly in these areas. 


\section{Development Requires Time}

Originally, the project period was planned for 3 years. Parallel to improving their structure and coordination, the schools worked on the programme to establish a common ground for their work. However, the project was prolonged by a second project phase of one and half years, it was important for the schools to move their focus to improving the quality of the teaching and learning processes.

The time factor was emphasised by all the school development coaches, due to the fact that most of the schools also experienced a phase of stagnation, or that their development work was put on hold due to other pressing priorities, for instance, the large number of refugees arriving to Germany in 2015. In some of the schools the sports hall was used for housing purposes, and they had to reorganise and prepare to start up "welcome classes". All the schools developed new school programmes and started to work on innovative teaching concepts and strategies to meet the needs of heterogenous student groups. However, the initiated changes did not reach the classrooms of all schools during the project period. One of the school development coaches stated the following:

[...] the teachers have stated: 'Yes, we want to do this, and we plan this...", in other words there is a shift in attitudes among staff, it was even noticed by the school inspectors. However, so far, this did not impact the teaching and this will take time. But the teachers are willing to change - this is clear (Interview, 2017).

This quote illustrates that there is a need to develop and improve organisational aspects as well as to work on a collective change of attitudes among staff before teachers are ready to take concrete steps to change their practice.

\section{Development Requires Support}

The school development coaches were regarded as important partners by the principals in initiating and implementing changes, and continuous and open conversations were highly valued. One of the principals particularly emphasised the role of the school development coach in backing her and the school up:

She always encouraged me to move on by reinforcing that this is the right direction and that we must continue. Personally, I perceived that she followed us through the process by her way of positive reinforcement (Interview, Principal, 2017)

The frequency of contact and meetings varied according to the needs of the principals and many of the school development coaches invested in the project,

We always had an open conversation and we usually talked a lot on the phone and on the weekends. It was intensive and productive, and we went through everything critically. In this school I did not have to deal with resistance from the principal. I coached her throughout the process, and we had at least weekly contact, either over the phone or we met in the school. I also had contact with the school staff (Interview, School Development Coach, 2017). 
The quote above also indicates possible problems in some schools. The degree of fit between the principal and the school development coach was crucial for their collaborative work. In some schools, the school development coach was replaced after a while. It was emphasised that the school development coaches needed work experience from the school system to understand the conditions and not just the school context.

Generally, the school development coaches viewed their roles as keeping the schools on track by reminding them what they previously had agreed on in meetings, by establishing new routines and by reflecting, together with the principals, the best way to make difficult decisions:

In the coaching sessions we had the opportunity to talk about issues that were not so easy to talk about in bigger groups, such as how to deal with staff who do not manage their tasks because of lack of competency (Interview, School Development Coach, 2017).

The support of LEA was particularly important with respect to hiring staff, where the responsibility of finding a suitable work environment for each teacher to identify and contribute to necessary change processes, such as key pedagogical concepts, was vital. As one representative stated:

You can only change a school through the people who work there. You would need to accept them as they are and start the process of convincing them. It is, however, a difficult and slow process [...] (Interview, 2017).

An important factor to succeed in improving these schools was described as the collective spirit and willingness to change, and some representatives expressed the wish to have more authority to reallocate teachers who were not willing to commit themselves to invest in necessary collective efforts.

\section{Improvement of the School's Organisation and Student Outcomes}

As previously described, the results of focusing on improving the school's organisation has led to better work environments and is demonstrated by strengthening school leadership, improving work conditions, increasing innovation capacity and intensifying cooperation among staff. These improvements were additionally demonstrated by several key figures in the new system of indicators, which was established by CEA during the project. For instance, in all the schools, the number of sick days and the number of cancelled lessons for staff decreased, as did the number of absence days for students (Huber et al., 2017). Moreover, the number of violent incidents decreased in schools where this was previously a problem. Finally, completion rates increase slightly and the number of students signing up for the lower secondary schools increased. The quantitative survey results of the ten project schools, as well as the indicator results reported above, showed a significant difference in improvement compared to schools that were selected for the comparison 
group. Even though some improvements with respect to the VERA-data can be observed, it is hard to relate this effect to the interventions and development work conducted by the schools. There is also a clear limitation of using such data, since the tests are conducted in 8th grade when students have completed 1 year in the integrated secondary schools. While the other types of data are longitudinal, these are cross-sectional, and it is questionable whether these data can be used to evaluate schools' success using a turnaround approach.

\section{Discussion and Conclusion}

The findings demonstrate how a model of school turnaround is influenced by school governing approaches, traditions and culture in a specific country. The results may contradict prevailing evidence-based logic of school turnaround approaches from the US, where the main indicator of change is the improvement of student performance as measured by standardised tests. Instead, the findings reflect the importance of project organisation, planning, timeline and involvement of stakeholders for the implementation process and project results.

Essential outcomes become clear: While the United States turnaround models are designed to be relatively radical with regard to school closures and staff layoffs, the project in Germany relies heavily on supporting the schools, empowering and increasing the competence of the school/internal stakeholders, and promoting various forms of cooperation with school/internal stakeholders. School leadership seems to be an important key factor in all projects. School leaders, who are able to restore the ability to act by establishing an appropriate leadership organisation and focus their work on pedagogical issues, play a special role. In England, there is a strong reliance on school networks, where schools in difficult situations collaborate, network, or even merge institutionally with successful schools in the area. Due to cultural and legal differences, solutions from the international context have to be examined closely, but within the framework of the melioristic function of international comparative educational research and educational planning, they represent an extremely interesting potential for simulation.

All of the strategies outlined in the above cases are part of school turnaround, but they are not a quick-fix recipe for success. To be successful in the long run, different approaches are needed that are tailored exactly to the unique circumstances of the individual school and contextualised to the respective school system. This paper reports various interventions integrated in a development process as a promising way to provide support to principals and schools according to their contextual challenges and individual needs. In our perspective, a 'turnaround process' needs to be viewed as a long-term process requiring concerted efforts with professional, profound and persistent action by all of the involved stakeholders. In addition to the intervention architecture, the school authorities and school leadership team are part of the first successful steps, followed by a gradual involvement of the entire staff. However, it should also be kept in mind that all school interventions are limited. 
Assuming that schools in difficult circumstances are often found in low SES catchment areas, and that the effect on a school explains about $10-40 \%$ of the variance in student achievement, it becomes clear that much more complex interventions are needed that go beyond the reach of the school and include the school environment. Schools cannot compensate for all the weaknesses and shortcomings of a community or a society, and no matter how well-intended and professional school development is, it cannot absorb the difficult social circumstances in which students live outside of school. Ultimately, the key to school improvement lies in political action and measures that focus not only on the individual school or the school system but also on community development in terms of poverty, unemployment, health deficits, deficient housing, educational difficulties and lack of life-management strategies of parents, to name but a few.

In the following we will summarise some important lessons learnt from the school turnaround project in Germany:

- School leadership is key to initiating and driving change, which are collectively supported

- School turnaround is a complex process and principals need support to lead the necessary change

- From top-down to participatory approaches, mid-level leaders can improve communication and transparency and ensure commitment

- Improved innovation capacity and cooperation are important factors for change and development

- Interventions are needed that are adaptive to the individual school's needs

Schools in difficult situations need targeted help in deriving school-specific goals from the programme objectives in conjunction with the organisational diagnosis. It is important to ensure coherence by focusing on improving the school's organisation first, by strengthening the leadership team and middle-management, focusing on staff work conditions and then building the innovation capacity through strengthening the cooperation between school actors. An overall improved school organisation provides a good basis to change and renew classroom practices along with agreed concepts and the school programme.

In addition, the overall intervention measures need to be managed well, and systematically coordinated measures must have clearly defined objectives. This may be easier in smaller organisational units. Overall, it is mainly about the work on structures and processes, the behaviour of staff members, and the other, undoubtedly complex, aspects that make up school culture.

Finally, suitable indicators of success need to be carefully selected by taking the interventions and development work of the schools into account as part of an adaptive and coherent evaluation. We argue that further research on development in schools in difficult circumstances is needed to further explore the contextual challenges of schools and what kind of interventions can contribute to improvement of the whole school's organisation, classroom practices and student outcomes in a broader sense. In further research, it is necessary to question what is counted as 'evidence' and the use and abuse of the term 'evidence-based' in school 
development processes that require highly contextualised knowledge and skills to initiate and drive change processes. According to the Norwegian philosopher Kvernbekk, 'based' in 'evidence-based' creates a misunderstanding (2011). She emphasizes that what makes something evidence is that it stands in a certain relation to a hypothesis, namely confirmation or disconfirmation. Her point is that 'facts are not made to support a hypothesis, but they can be recognized as supportive or not supportive' (2011, p. 532). Evidence-based practice suggests that we choose - in this case - an approach to school development which is well supported.

\section{References}

Ainscow, M., West, M., \& Nicolaidou, M. (2004). Putting our heads together: A study of headteacher collaboration as a strategy for school improvement. In P. Clarke (Ed.), Improving schools in difficulty (pp. 117-136). Continuum.

Altrichter, H., Gußner, N., \& Maderthaner, P. (2008). Failing schools-Auf der Suche nach der, schlechten Schule. Ein Literaturüberblick [In search of the "bad school". A literature review]. Journal für Schulentwicklung, 1, 43-55.

Altrichter, H., \& Merki, K. M. (2010). Handbuch Neue Steuerung im Schulsystem. Springer.

Altrichter, H., \& Moosbrugger, R. (2011). Schulen in Schwierigkeiten. Was sagt die Schulforschung über Anzeichen, Ursachen und Lösungen? [Schools in Difficulties. What does research say about characteristics, reasons and solutions]. Lernende Schule, 14(56), 8-11.

Baumert, J., Stanat, P., \& Watermann, R. (2006). Herkunftsbedingte Disparitäten im Bildungswesen. Vertiefende Analysen im Rahmen von PISA 2000. VS Verlag für Sozialwissenschaften.

Böttcher, W., \& Kotthoff, H.-G. (2007). Schulinspktion: Evaluation, Rechenschaftslegung und Qualitätsentwickling. Waxmann.

Bryk, A. S., Gomez, L. M., Grunow, A., \& LeMehieu, P. G. (2015). Learning to improve. How America's schools can get better at getting better. Harward Education Press.

Clarke, P. (2004). Endpiece: Legitimacy and action. In P. Clarke (Ed.), Improving schools in difficulty (pp. 172-181). Continuum.

Connelly, F. M., Clandinin, D. J., \& Applebaum, S. D. (Eds.). (1999). Shaping a professional identity: Stories of educational practice. Teachers College Press.

Cronbach, L., Gleser, G. C., Nanda, H., \& Nageswari R. (1972). The dependability of behavioral measurements. Theory of generalizability for scores and profiles. Wiley.

Datnow, A., \& Stringfield, S. (2000). Working together for reliable school reform. Journal of Education for Students Placed at Risk (JESPAR), 5(1-2), 183-204.

Gunter, H., Hall, D., Serpieri, R., \& Grimaldi, E. (2016). New public management and the reform of education: European lessons for policy and practice. Routledge.

Harris, A., \& Chapman, C. (2002). Leadership in schools facing challenging circumstances. Management in Education, 16(1), 10-13.

Hochbein, C. (2012). Relegation and reversion: Longitudinal analysis of school turnaround and decline. Journal of Education for Students Placed at Risk, 17(1-2), 92-107.

Hopmann, S. T. (2008). No child, no school, no state left behind: Schooling in the age of accountability. Journal of Curriculum Studies, 40(4), 417-456.

Huber, S. G. (2013). Perspektiven für Schulen in kritischer Lage. Expertise zum Projekt „School Turnaround: Berliner Schulen starten durch“. Robert Bosch Stiftung.

Huber, S. G. (2018). No simple fixes for schools in challenging circumstances. Contextualisation for Germany. In C. Meyers (Ed.), International perspectives on leading low-performing schools (pp. 243-266). Information Age Publishing. 
Huber, S. G., Hader-Popp, S., \& Schneider, N. (2014). Qualität und Entwicklung von Schule: Basiswissen Schulmanagement. Beltz.

Huber, S. G., \& Muijs, R. (2012). Schulentwicklung bei besonders belasteten Schulen. Schulverwaltung spezial, 14(2), 9-13.

Huber, S. G., Skedsmo, G., Pham, G. H., Koszuta, A., Karwat, K., Schwander, M., Kots, S., \& Luig, C. (2017). Schlussbericht der wissenschaftlichen Begleitung zum Projekt School Turnaround. Report.

Kutash, J., Nico, E., Gorin, E., Rahmatullah, S., \& Tallant, K. (2010). The school turnaround field guide. Social impact advisors. New York: FSG Social Impact Advisors. Abgerufen von http:// www.wallacefoundation.org/knowledge-center/Documents/The-School-Turnaround-FieldGuide.pdf

Kvernbekk, T. (2011). The concept of evidence in evidence-based practice. Educational Theory, $61(5), 515-532$.

Levy, J. (2019). Methodological issues in value-added modeling: An international review from 26 countries. Educational Assessment, Evaluation and Accountability, 31(3), 257-287.

Meyers, C. V. (2013). School turnaround as National Policy in the United States: Considerations from three studies conducted in the Midwest. Journal of International and Comparative Education, 2(2), 98-11.

Meyers, C. V., \& Hitt, D. H. (2017). Planning for school turnaround in the United States: An analysis of the quality of principal-developed quick wins. School Effectiveness and School Improvement, 29(3), 362-382.

Meyer, C., Wronowski, M., \& Van Groningen, B. (2021). Preparing for the worst: Identifying predictors of school decline as an improvement initiative. Educational Assessment, Evaluation and Accountability, 33(2), 255-290.

Mintrop, H. (2004). High-stakes accountability, state oversight, and educational equity. Teachers College Record, 106(11), 2128-2145.

Muijs, D., Harris, A., Chapman, C., Stoll, L., \& Russ, J. (2004). Improving schools in socioeconomically disadvantaged areas: An overview of research. School Effectiveness and School Improvement, 15(2), 149-176.

Murphy, J. (2008). The place of leadership in turnaround schools: Insights from organizational recovery in the public and private sectors. Journal of Educational Administration, 46(1), 74-98.

Murphy, \& Meyers. (2008). Turning around failing schools: Leadership lessons from the organizational sciences. Corwin Press.

Potter, D., Reynolds, D., \& Chapman, C. (2002). School improvement for schools facing challenging circumstances: A review of research and practice. School Leadership \& Management, 22(3), 243-256.

Racherbäumer, K., Funke, C., van Ackeren, I., \& Clausen, M. (2013). Datennutzung und Schulleitungshandeln an Schulen in weniger begünstigter Lage. Empirische Befunde zu ausgewählten Aspekten der Qualitätsentwicklung. In Die Deutsche Schule 13, Beiheft 12, S (pp. 226-254). Waxmann.

Reid, W. A. (1998). Systems and structures or myths and fables? A cross-cultural perspective on curriculum content. In B. B. Gundem \& S. T. Hopmann (Eds.), Didaktik and/or curriculum: An international dialogue. Peter Lang.

Webb, P. T. (2006). The choreography of accountability. Journal of Education Policy, 21(2), 201-214.

Westbury, I., Hopmann, S., \& Riquarts, K. (2000). Teaching as a reflelctive practice. The German Didaktik Tradition. Routledge.

Williamson, B. (2017). Big Data in education: The digital future of learning, policy and practice. Sage. 
Open Access This chapter is licensed under the terms of the Creative Commons Attribution 4.0 International License (http://creativecommons.org/licenses/by/4.0/), which permits use, sharing, adaptation, distribution and reproduction in any medium or format, as long as you give appropriate credit to the original author(s) and the source, provide a link to the Creative Commons license and indicate if changes were made.

The images or other third party material in this chapter are included in the chapter's Creative Commons license, unless indicated otherwise in a credit line to the material. If material is not included in the chapter's Creative Commons license and your intended use is not permitted by statutory regulation or exceeds the permitted use, you will need to obtain permission directly from the copyright holder. 